\title{
STRATEGI KEBIJAKAN PENINGKATAN JUMLAH MAHASISWA DALAM MEMUTUSKAN MEMILIH PROGRAM PASCASARJANA DI DEPARTEMEN ESL FEM IPB
}

\author{
POLICY STRATEGY INCREASES THE NUMBER OF STUDENTS IN CHOOSING POSTGRADUATE \\ PROGRAM IN THE ESL DEPARTMENT FEM IPB
}

\author{
Mahmudah $^{*) 1}$, Lukman Mohammad Baga**), dan Siti Amanah ${ }^{* * *}$ \\ *) Departemen Ekonomi Sumberdaya dan Lingkungan, Fakultas Ekonomi dan Manajemen, IPB University \\ Jl. Agatis Kampus IPB Darmaga, Bogor 16680 \\ ${ }^{* *}$ Departemen Agribisnis, Fakultas Ekonomi dan Manajemen, IPB University \\ Jl. Kamper, Wing 4 Level 5, Kampus IPB Dramaga, Bogor 16680 \\ ${ }^{* * *}$ Departemen Sains Komunikasi dan Pengembangan Masyarakat, Fakultas Ekologi Manusia, IPB University \\ Jl. Kamper, Wing 1 Level 5, Kampus IPB Dramaga, Bogor 16680
}

\begin{abstract}
Department of Resources and Environmental Economics (ESL Department) is one of the departments under the Faculty of Economics and Management, IPB University and running the Postgraduate program. This research aimed to formulate alternatives policy based on the factors that influence students' decision to choose a postgraduate program in the ESL department FEMIPB. The research was carried out by using Analytical Hierarchy Process (AHP). The data were collected by interviews with 14 respondents namely the Dean of the Graduate School IPB, the Dean of the Faculty of Economics and Management, The Head of the ESL Department FEM IPB, three Heads of Study Program in the ESL Department FEM IPB, two lectures, four active students of the Postgraduate Program, and two alumni of the Postgraduate program at the ESL Department FEM IPB. The results of the AHP analysis showed that the main factor was the product. The priority actor was the head of the study program. The overall priority strategy to increase the student number was to offer collaboration to several institutions both in domestic and abroad.
\end{abstract}

Keywords: ESL department students, postgraduate programs, AHP

\begin{abstract}
Abstrak: Departemen Ekonomi Sumberdaya dan Lingkungan (Departemen ESL) merupakan salah satu Departemen yang berada di bawah Fakultas Ekonomi dan Manajemen, Institut Pertanian Bogor dan sebagai salah satu unit pengelola program pascasarjana. Penelitian ini bertujuan untuk merumuskan alternatif kebijakan dari faktorfaktor yang memengaruhi keputusan mahasiswa dalam memilih program pascasarjana di Departemen ESL FEM IPB dalam upaya meningkatkan jumlah mahasiswa. Penelitian dilakukan dengan menggunakan metode Analytical Hierarchy Process (AHP). Teknik pengumpulan data dengan wawancara aktor dan pengisian kuesioner oleh 14 responden yaitu Dekan Sekolah Pascasarjana IPB, Dekan Fakultas Ekonomi dan Manajemen, Ketua Departemen ESL FEM IPB, tiga orang Ketua Program Studi di lingkungan Departemen ESL FEM IPB, dua orang Dosen, empat orang mahasiswa Program Pascasarjana yang masih aktif, dan dua orang alumni Program Pascsarajana di Departemen ESL FEM IPB. Hasil analisis AHP memperlihatkan bahwa faktor yang menjadi prioritas secara keseluruhan adalah produk. Aktor yang menjadi prioritas secara keseluruhan yaitu Ketua Program Studi. Strategi prioritas dalam upaya meningkatkan jumlah mahasiswa adalah menawarkan kerjasama ke beberapa lembaga baik di dalam maupun di luar negeri.
\end{abstract}

Kata kunci: departemen ESL, program pascasarjana, AHP

\footnotetext{
${ }^{1}$ Alamat Korespondensi:

Email: arkanadha@gmail.com
} 


\section{PENDAHULUAN}

Departemen Ekonomi Sumberdaya dan Lingkungan (ESL) merupakan salah satu Departemen pada Fakultas Ekonomi dan Manajemen (FEM) Institut Pertanian Bogor (IPB) sebagai penyelenggara pendidikan tinggi dengan mengikuti standar pendidikan yang telah ditetapkan pada Peraturan Pemerintah Republik Indonesia Nomor 19 Tahun 2005. Menurut peraturan pemerintah tersebut, Departemen bertanggungjawab dalam pelaksanaan pendidikan (Sekneg, 2005). Salah satu pelaksanaan pendidikan yang dilakukan oleh Departemen adalah pengelolaan penyelenggaraan pendidikan Program Magister dan Program Doktor pada Program Studi. Program Studi adalah kesatuan kegiatan pendidikan dan pembelajaran yang memiliki kurikulum dan metode pembelajaran tertentu dalam satu jenis pendidikan akademik, pendidikan profesi, dan/atau pendidikan vokasi (Undang-Undang nomor 12 tahun 2012 tentang Pendidikan Tinggi).

Sehubungan dengan adanya penataan Departemen yang dilakukan oleh IPB pada tahun 2005, maka Program Studi yang berbasis sosial ekonomi terintegrasi di Departemen Ekonomi Sumberdaya dan Lingkungan dibawah Fakultas Ekonomi dan Manajemen IPB (SK Rektor IPB nomor: 001/K13/PP/2005 tentang penataan Departemen). Departemen Ekonomi Sumberdaya dan Lingkungan (Departemen ESL) menjadi unit pengelola 5 (lima) Program Studi Pascasarjana yakni Program Magister dan Doktor Ilmu Ekonomi Pertanian (EPN), Program Magister dan Program Doktor Ekonomi Kelautan Tropika (EKT), dan Program Magister Ekonomi Sumberdaya dan Lingkungan (ESL). Program Studi EPN merupakan program pascasarjana yang sebelumnya di bawah pengelolaan Jurusan Ilmuilmu Sosial Ekonomi Pertanian, Fakultas Pertanian. Program Studi EKT sebelumnya dikelola oleh Jurusan Sosial Ekonomi Perikanan, Fakultas Perikanan dan Ilmu Kelautan. Program Studi ESL berdiri pada tahun 2008 setelah ada lulusan Program Sarjana Departemen ESL.

Integrasi program pascasarjana di Departemen ESL ini tidak diimbangi dengan integrasinya SDM terutama tenaga pendidik (dosen). Hal ini perlu diperhatikan mengingat surat dari BAN-PT nomor: 768/BAN-PT/ LL/2017 tentang persyaratan jumlah dan kualifikasi dosen dalam dalam proses akreditasi. BAN-PT memberikan syarat dalam pengelolaan satu Program Studi jumlah dosen tetap yang ditugaskan secara penuh waktu untuk menjalankan proses pembelajaran pada setiap Program Studi paling sedikit enam orang dan dosen tetap untuk Program Doktor paling sedikit memiliki dua orang profesor.

Departemen ESL dalam menjalankan mandatnya mengelola program pascasarjana selain memperhatikan jumlah dosen perlu juga memperhatikan salah satu input lainnya. Salah satu input dalam penyelenggaraan Program Studi program pascasarjana adalah mahasiswa. Perkembanganjumlahmahasiswa program pascasarjana di Departemen ESL FEM IPB pada lima tahun terakhir mengalami penurunan. Penurunan jumlah mahasiswa ini perlu diperhatikan karena menurut Harwani et al. (2018) di Indonesia, salah satu keberhasilan perguruan tinggi dapat dilihat antara lain dari banyaknya peminat dan jumlah mahasiswa sesuai dengan kapasitas yang mereka miliki.

Demikian juga dalam era globalisasi yang mendorong ilmu pengetahuan dan teknologi berkembang sangat yang cepat, sehingga membuat semua informasi sangat mudah diakses dan tanpa batas. Informasi penyelenggaraan pendidikan program pascasarjana baik di luar negeri maupun di dalam negeri sangat mudah didapatkan. Mahasiswa dapat dengan mudah memperoleh informasi mengenai Program Studi Pascasarjana yang akan dipilihnya. Informasi pendaftaran online Program Studi Pascasarjana sudah hampir dilakukan oleh seluruh perguruan tinggi di Indonesia. Penawaran perkuliahan online juga telah dilakukan oleh beberapa perguruan tinggi terbaik di Indonesia (Topan, 2018).

Tawaran Program Studi yang memiliki satu rumpun ilmu dengan Program Studi Pascasarjana di Departemen ESL FEM IPB telah dilakukan juga oleh Departemen lain di Institut Pertanian Bogor. Salah satunya adalah program pascasarjana Agribisnis dan Sekolah Bisnis IPB yang menawarkan program pascasarjana dengan kerjasama beberapa sponsor. Hal ini tentunya menimbulkan persaingan. Persaingan yang tinggi antara perguruan tinggi di Indonesia baik negeri maupun swasta dalam menarik mahasiswa dan tingginya perkembangan teknologi komunikasi informasi mengakibatkan derasnya arus informasi ke masyarakat. Dengan demikian perguruan tinggi terutama Departemen sebagai unit pengelola harus mampu menampilkan Program Studi yang kompetitif untuk ditawarkan kepada masyarakat. 
Perkembangan mahasiswa pada program pascasarjana di Departemen ESL FEM IPB dapat dilihat pada Gambar 1. Gambar 1 menunjukkan penurunan jumlah mahasiswa program pascasarjana di Departemen ESL FEM IPB periode penerimaan Tahun Ajaran 2014/2015 sampai dengan Tahun Ajaran 2018/2019. Jumlah penurunan mahasiswa secara signifikan terjadi pada Program Doktor PS-EKT dengan jumlah mahasiswa 1 orang. Kenaikan jumlah mahasiswa yang signifikan terjadi pada tahun 2014/2015 pada Program Magister PS-ESL sejumlah 27 orang.

Artini et al. (2014) mengemukakan bahwa faktor yang memengaruhi keputusan mahasiswa dalam memilih jurusan diantaranya adalah produk, promosi, kemauan sendiri, dan kelompok acuan. Penelitian Kurniawati (2013) dengan menggunakan analisis regresi menemukan bahwa keputusan mahasiswa memilih Universitas Katolik Widya Mandala Madiun dipengaruhi diantarnya oleh faktor produk/ program studi dan promosi. Mulyatini et al. (2014) dalam penelitiannya bahwa salah satu faktor yang berpengaruh terhadap keputusan memilih Program Studi adalah faktor promosi. Erdawati (2014) dengan menggunakan analisis regresi berganda menyatakan bahwa salah satu faktor yang memengaruhi keputusan mahasiswa memilih STIE Pasaman Simpang Empat adalah promosi.

Penelitian yang dilakukan oleh Wulandini dan Saputra (2017) menemukan bahwa salah satu faktor yang memiliki pengaruh signifikan terhadap pengambilan keputusan mahasiswa memilih perguruan tinggi swasta di Pekanbaru adalah promosi. Wiliana (2018) menyatakan bahwa beberapa faktor yang berpengaruh signifikan terhadap keputusan mahasiswa memilih Program Studi di Fakultas Ilmu Kesehatan Universitas
Muhammadiyah Tangerang adalah faktor internal (harga, produk, lokasi, promosi) dan faktor eksternal (pendapatan keluarga dan kemauan sendiri). Fakhri et al. (2017) mengemukakan bahwa salah satu faktor yang mempengaruhi mahasiswa memilih program studi adalah promosi kampus.

Memilih Program Studi pada Sekolah Pascasarjana dipengaruhi oleh beberapa faktor, hasil penelitian Mahmudah et al. (2019) dengan menggunakan analisis regresi berganda menyatakan bahwa faktor yang signifikan memengaruhi keputusan mahasiswa memilih program pascasarjana di Departemen ESL FEM IPB adalah produk, promosi dan kemauan sendiri. Hasil penelitian tersebut digunakan untuk membangun struktur hirarki yang dilakukan dalam penelitian ini. Hal ini dilakukan untuk memberikan gambaran perumusan alternatif kebijakan dalam upaya meningkatkan jumlah mahasiswa pada program pascasarjana di Departemen ESL FEM IPB sebagai tujuan dari penelitian ini.

Perumusan masalah pada penelitian ini bahwa selama lima tahun terakhir perkembangan jumlah mahasiswa program pascasarjana di Departemen ESL FEM IPB mengalami penurunan. Selain itu, terdapat berbagai masalah seperti kurangnya jumlah SDM terutama dalam proses penyelenggaraan program pascasarajana di Departemen ESL dan munculnya program studi yang memiliki ilmu serumpun yang ditawarkan. Hal tersebut dijadikan landasan untuk mendapatkan strategi yang tepat dalam upaya meningkatkan jumlah mahasiswa. Tujuan penelitian ini adalah merumuskan alternatif kebijakan dari faktor-faktor yang memengaruhi keputusan mahasiswa dalam memilih program pascasarjana di Departemen ESL FEM IPB dalam upaya meningkatkan jumlah mahasiswa.

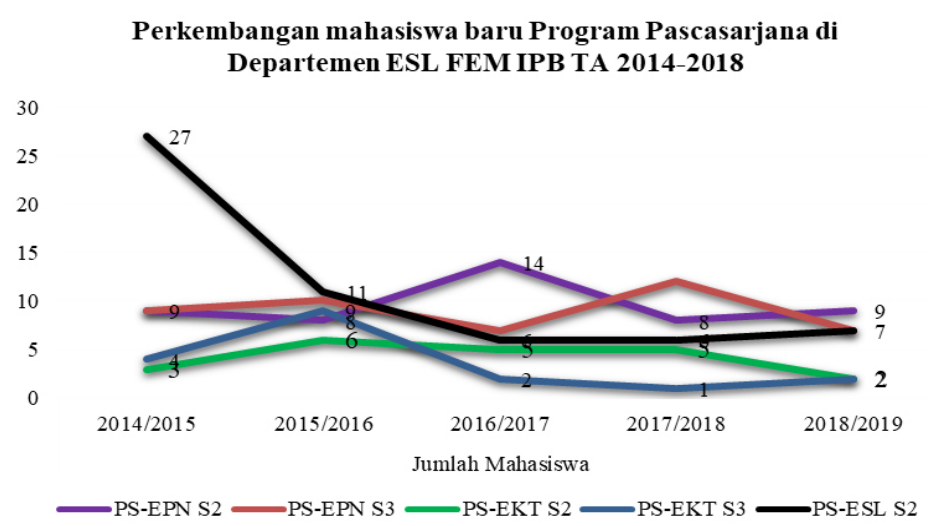

Gambar 1. Perkembangan mahasiswa baru program pascasarjana di Departemen ESL FEM IPB TA 2014-2018 (IPB, 2018) 
Hasil penelitian diharapkan dapat memberikan sumbangan pemikiran bagi institusi secara ilmiah tentang alternatif kebijakan dalam meningkatkan jumlah mahasiswa program pascasarjana di Departemen ESL FEM IPB sebagai referensi pendidikan. Selain itu juga dapat menjadi sumbangan pemikiran dalam upaya peningkatan jumlah mahasiswa memilih program pascasarjana di Departemen ESL FEM IPB. Penelitian ini juga dapat memberikan kontribusi praktis, berupa pemahaman terhadap unsur, faktor dan alternatif kebijakan sehingga dapat menjadi dasar untuk membuat rencana-rencana pengelolaan dan pengembangan yang strategis di Departemen ESL FEM IPB khususnya dan IPB pada umumnya.

\section{METODE PENELITIAN}

Penelitian dilaksanakan pada Program Pascasarjana di Departemen ESL FEM IPB tanggal 1 April 2019 sampai dengan 5 Juni 2019. Data yang digunakan berupa data primer dan data sekunder. Data primer diperoleh dari hasil analisa wawancara dengan para aktor yang menjadi responden dalam penelitian ini dan dari hasil penelitian Mahmudah et al. (2019). Data sekunder diperoleh dari jurnal, buku, RENSTRA Departemen ESL FEM IPB, dan sumber lain yang berhubungan dengan penelitian ini.

Data dan informasi dari responden dikumpulkan menggunakan instrumen kuesioner yang terstruktur. Pertanyaan diajukan kepada responden, di mana responden diminta memberikan jawaban atas pertanyaan tersebut (Sumarwan et al. 2013). Responden ditentukan dengan menggunakan cara purposive sampling, yakni tenik penentuan sampel dengan pertimbangan tertentu (Sugiyono, 2007). Dharmawansyah et al. (2014) mengemukakan bahwa purposive sampling adalah sampel bertujuan. Responden merupakan para aktor yang berperan dalam kegiatan akademik Program Pascasarjana di Departemen ESL FEM IPB. Responden terdiri dari Dekan Sekolah Pascasarjana IPB, Dekan Fakultas Ekonomi dan Manajemen IPB, Ketua Departemen ESL, Ketua Program Studi, sebagai aktor pemangku kebijakan. Dosen merupakan salah satu aktor pelaksana kebijakan. Sedangkan mahasiswa dan alumni merupakan aktor yang merasakan kebijakan.
Metode Analytical Hierarchy Process (AHP) digunakan untuk memberikan kesempatan agar setiap pihak dapat membangun gagasan-gagasan dan mendefinisikan persoalan dengan cara membuat asumsi mereka masing-masing sehingga diperoleh suatu pemecahan yang diinginkan darinya (Ichwani et al. 2019). Menurut Saaty (1993) yang diacu dalam Triyonggo (2016) bahwa prinsip kerja AHP adalah penyederhanaan suatu persoalan kompleks yang tidak terstruktur, strategik, dan dinamik menjadi bagian-bagian dan tertata dalam suatu hirarki. Untuk berbagai persoalan, skala 1 sampai 9 adalah skala terbaik dalam mengekspresikan pendapat, sesuai dengan nilai dan definisi pendapat kualitatif dari skala perbandingan Saaty dapat dilihat pada Tabel 1.

Dalam metode AHP, tingkat inkonsistensi yang masih dapat diterima adalah sebesar 10 persen. Jadi jika nilai Rasio Konsistensi (RK) $\leq$ 0,1 (10 persen), maka hasil perbandingan preferensi konsisten dan sebaliknya jika RK $>0,1$ (10 persen) maka hasil perbandingan preferensi tidak konsisten. Apabila tidak konsisten maka terdapat dua pilihan, yaitu mengulang perbandingan preferensi atau melakukan proses autokoreksi.

Dengan menggunakan AHP, suatu persoalan akan diselesaikan dalam suatu kerangka pemikiran yang terorganisir sehingga dapat diekspresikan untuk mengambil keputusan yang efektif atas persoalan tersebut. Persoalan yang kompleks dapat disederhanakan dan dipercepat proses pengambilan keputusannya. Oleh karena itu, analisis prioritas kebijakan program pascasarjana di Departemen ESL FEM IPB untuk meningkatkan jumlah mahasiswa dilakukan untuk menentukan alternatif kebijakan dengan metode AHP.

Penelitian ini diawali dengan mengidentifikasi faktorfaktor yang memengaruhi keputusan mahasiswa memilih program pascasarjana di Departemen ESL FEM IPB dari hasil penelitian Mahmudah et al. (2019). Identifikasi alternatif kebijakan peningkatan jumlah mahasiswa dianalisis menggunakan metode AHP. Rekomendasi kebijakan disusun berdasarkan hasil analisis tersebut. Metode ini menghasilkan alternatif kebijakan berdasarkan penilaian responden. Kerangka pemikiran dapat dilihat pada Gambar 2. 
Tabel 1 Skala penilaian perbandingan

\begin{tabular}{cl}
\hline Intensitas Kepentingan & Keterangan \\
\hline 1 & Kedua elemen sama pentingnya \\
3 & Elemen yang satu sedikit lebih penting daripada elemen yang lainnya \\
5 & Elemen yang satu lebih penting daripada elemen yang lainnya \\
7 & Satu elemen jelas lebih mutlak penting daripada elemen yang lainnya \\
9 & Satu elemen mutlak penting daripada elemen lainnya \\
$2,4,6,8$ & Nilai-nilai diantara dua nilai pertimbangan yang berdekatan \\
\hline
\end{tabular}

Sumber: Saaty (1993)

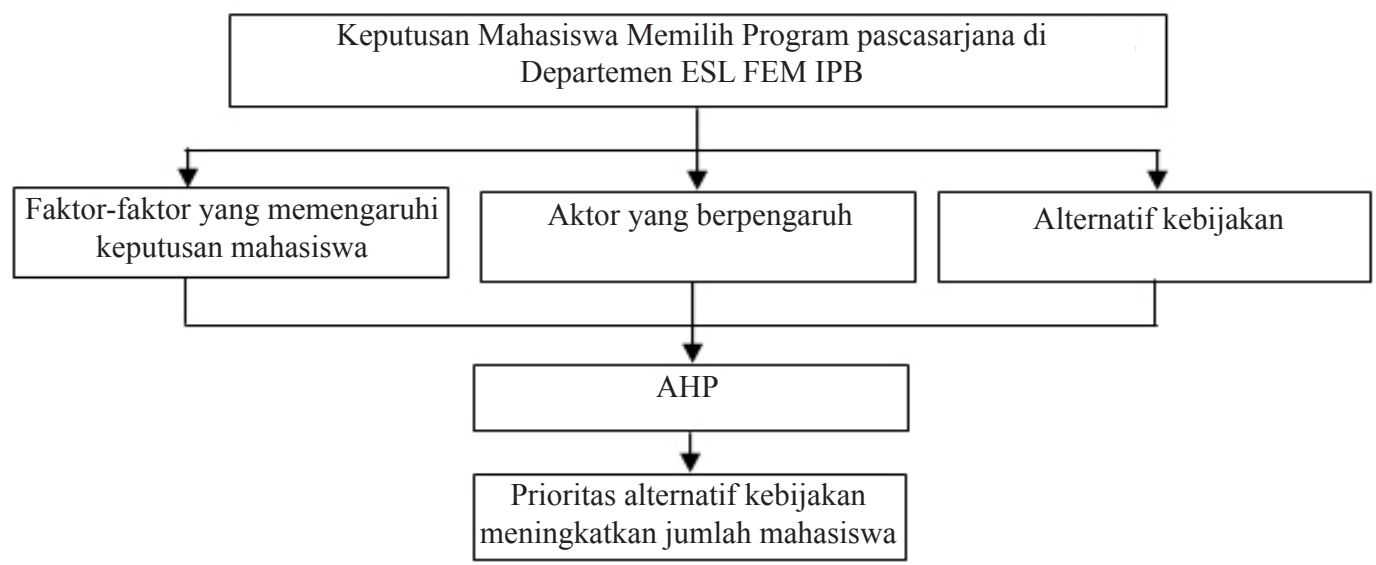

Gambar 2. Kerangka pemikiran

\section{HASIL}

\section{Faktor-faktor yang Memengaruhi Keputusan Mahasiswa Memilih Program Pascasarjana di Departemen ESL FEM IPB}

Hasil penelitian Mahmudah et al. (2019) dengan menggunakan analisis regresi berganda menunjukkan bahwa faktor-faktor yang signifikan memengaruhi keputusan mahasiswa memilih program pascasarjana di Departemen ESL FEM IPB adalah produk, promosi dan kemauan sendiri. Faktor-faktor tersebut digunakan untuk membangun struktur hirarki dalam penelitian untuk mengetahui alternatif kebijakan dalam upaya meningkatkan jumlah mahasiswa. Untuk mengetahui prioritas alternatif kebijakan untuk meningkatkan jumlah mahasiswa dalam penelitian ini digunakan AHP.

\section{Hasil AHP}

Analisis yang digunakan dalam prioritas alternatif kebijakan peningkatan jumlah mahasiswa adalah Proses Hirarki Analitik (PHA). Hasil pendapat para aktor yang menjadi responden dianalisis menggunakan
Software Expert Choice. Penilaian dari aktor dianggap konsisten apabila memiliki Consistency Ratio (CR) tidak lebih dari 0,10 .

\section{Pengolahan Vertikal}

Pengolahan data secara vertikal dilakukan untuk menyusun prioritas setiap elemen dalam hirarki terhadap goal prioritas alternatif kebijakan program pascasarjana di Departemen ESL FEM IPB untuk meningkatkan jumlah mahasiswa. Hasil AHP secara lengkap dapat dilihat pada Gambar 3.

Dalam merancang suatu sistem berbasis metode AHP untuk pengambilan keputusan maka langkah awal yang harus dilakukan adalah mendefinisikan permasalahan dan penentuan tujuan dengan menyusunnya kedalam hierarki, selanjutnya menentukan kriteria yang akan diberikan bobotnya (Suhud dan Dwiyatno, 2014). Gambar 2 menunjukkan struktur hirarki yang dibangun dengan goal penelitian adalah prioritas alternatif kebijakan program pascasarjana di Departemen ESL FEM IPB untuk meningkatkan jumlah mahasiswa. Faktor-faktor yang digunakan dalam membangun struktur yaitu produk, promosi dan kemauan sendiri. 
Aktor yang berperan untuk mendukung struktur diambil dari pemangku kebijakan, pelaksana kebijakan dan yang merasakan kebijakan. Dekan Sekolah Pascasarjana IPB, Dekan Fakultas Ekonomi dan Manajemen IPB, Ketua Departemen ESL, Ketua Program Studi, sebagai aktor pemangku kebijakan. Dosen merupakan salah satu aktor pelaksana kebijakan, sedangkan mahasiswa dan alumni merupakan aktor yang merasakan kebijakan. Alternatif kebijakan yang digunakan merupakan hasil wawancara mendalam dengan beberapa aktor, yaitu membuka program peminatan dan menawarkan program yang kompetitif, promosi langsung ke lembaga pemerintah dan swasta, promosi dengan memanfaatkan media sosial yang ada, dan menawarkan kerjasama ke beberapa lembaga baik di dalam negeri maupun di luar negeri.

\section{Analisis Unsur Faktor terhadap Prioritas Alternatif Kebijakan untuk meningkatkan jumlah mahasiswa}

Analisis unsur faktor bertujuan melihat tingkat pengaruh suatu unsur faktor terhadap goal, yaitu prioritas alternatif kebijakan program pascasarjana di Departemen ESLFEM IPB untuk meningkatkan jumlah mahasiswa. Unsur faktor terdiri dari produk, promosi, dan kemauan sendiri. Bobot dan prioritas unsur faktor dapat di lihat pada Tabel 2.

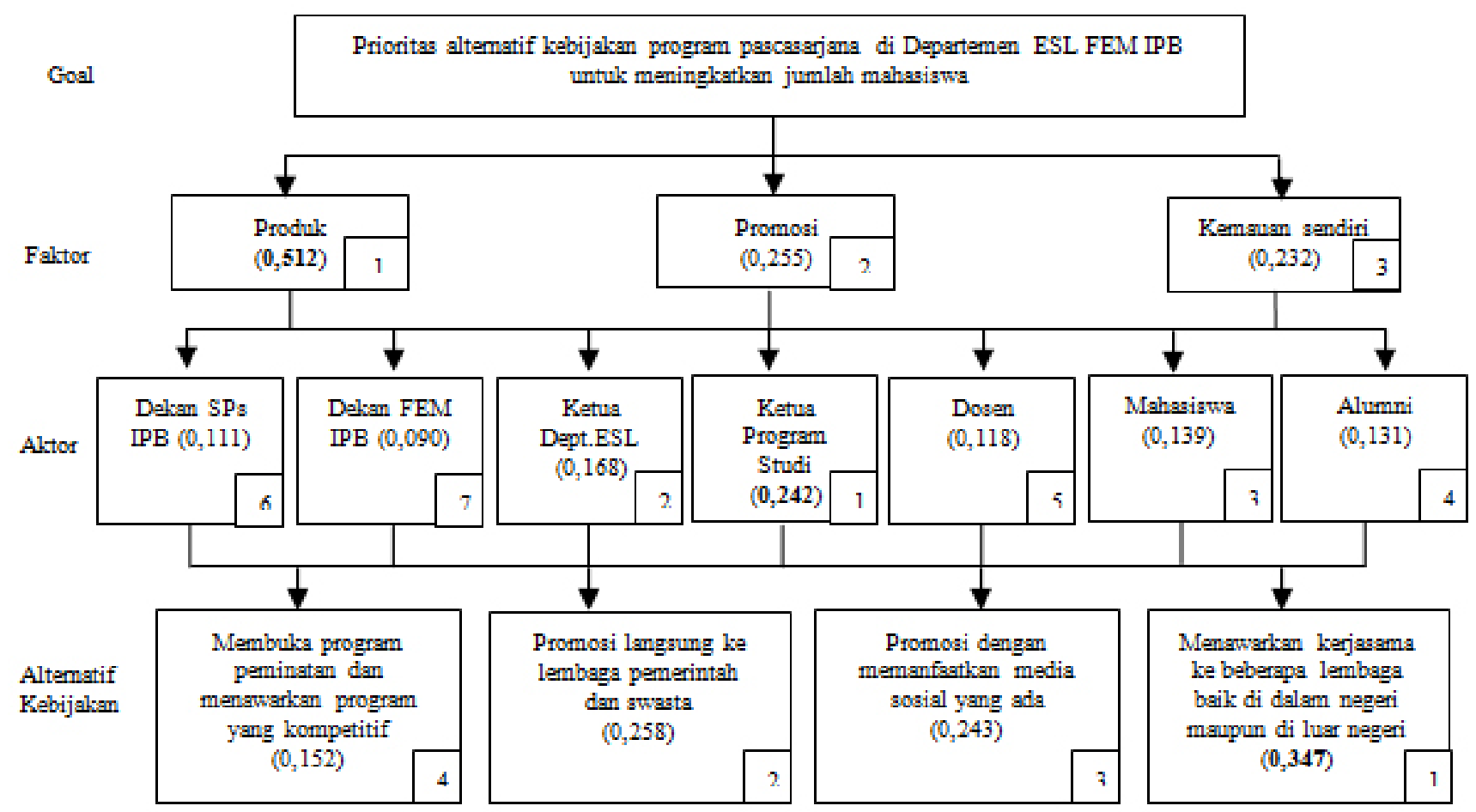

Gambar 3. Struktur hirarki prioritas alternatif kebijakan program pascasarjana di Departemen ESL FEM IPB untuk meningkatkan jumlah mahasiswa.

Tabel 2 Bobot dan prioritas faktor terhadap alternatif kebijakan untuk meningkatkan jumlah mahasiswa

\begin{tabular}{lcc}
\hline Unsur faktor & Bobot & Prioritas \\
\hline Produk & 0,512 & 1 \\
Promosi & 0,255 & 2 \\
Kemauan Sendiri & 0,232 & 3 \\
\hline
\end{tabular}


Tabel 2 menunjukkan bahwa faktor yang memiliki tingkat pengaruh terbesar dalam prioritas alternatif kebijakan meningkatkan jumlah mahasiswa adalah produk $(0,512)$. Menyusul faktor lain berikutnya yaitu promosi $(0,255)$ dan kemauan sendiri $(0,232)$. Faktor produk (Program Studi) menjadi prioritas utama dalam rangka meningkatkan jumlah mahasiswa, karena kondisi sekarang persaingan produk pemasaran jasa perguruan tinggi sangat ketat dengan dibukanya pendaftaran online yang dilakukan oleh hampir semua perguruan tinggi baik di dalam negeri maupun di luar negeri. Adanya pembukaan program yang serumpun oleh beberapa unit pengelola Departemen baik di dalam IPB sendiri juga di beberapa perguruan tinggi yang lain. Hal ini perlu diperhatikan oleh Program Pascsarjana di Departemen ESL FEM IPB. Terutama perlu adanya penyegaran produk (Program Studi) dengan kualitas yang baik, sesuai dengan perkembangan ilmu pengetahuan dan teknologi serta kebutuhan pasar dunia kerja. Hal ini sejalan dengan apa yang akan dilakukan oleh program pascasarjana di Departemen ESL FEM IPB yaitu pembukaan peminatan program Ilmu Ekonomi Pertanian dan Program Ekonomi Kelautan Tropika yang harus diiringi dengan komitmen yang tinggi oleh pengelola.

\section{Program pascasarjana di Departemen ESL FEM IPB} merupakan Program Studi yang spesifik sehingga para peminatnyajuga sangatspesifik. Hal ini berbanding lurus dengan hasil penelitian Mahmudah et al. (2019) yang menunjukkan bahwa rata-rata peminat Program Studi PascasarjanadiDepartemenESLadalahmahasiswayang sudah memiliki pekerjaan tetap baik di swasta maupun di instansi negeri, baik sebagai akademisi maupun peneliti. Dua alasan tertinggi mahasiswa melanjutkan studi di program pascasarjana Departemen ESL FEM IPB adalah (1) Mengembangkan dan memperluas ilmu pengetahuan di bidang yang baru, dan (2) Meningkatkan pengetahuan, pemahaman dan keterampilan di bidang pekerjaan yang digelutinya. Oleh sebab itu, penting juga dilakukan pengembangan Program kerjasama riset dengan instansi tempat mahasiswa bekerja yang perlu dilakukan secara konsisten dan serius oleh pengelola program pascasarjana di Departemen ESL FEM IPB.

Unsur faktor yang menjadi prioritas kedua adalah promosi dengan nilai bobot sebesar 0,255. Promosi merupakan salah satu faktor penting dalam menginformasikan kualitas sebuah produk, karena salah satu tujuan dilakukannya promosi adalah mengubah tingkah laku dan pendapat konsumen (Siregar dan
Panjaitan, 2018). Hal ini sejalan dengan pendapat yang dikemukakan oleh Setyowati dan Aesthetika (2017) kualitas sebuah lembaga perguruan tinggi akan diketahui masyarakat luas apabila adanya kegiatan promosi, dengan adanya promosi yang dilakukan, maka akan menghasilkan suatu opini dalam pengambilan keputusan. Jika institusi pendidikan tinggi ingin mendapatkan siswa yang lebih banyak dibanding yang lain, maka diperlukan iklan perusahaan atau melakukan kegiatan pomosi yang menjadi penghubung antara mahasiswa dan institusi (Jayawinangun et al. 2014).

Hasil penelitian menunjukkan bahwa promosi yang dilakukan oleh program pascasarjana Departemen ESL FEM IPB dapat memengaruhi keputusan mahasiswa. Sumber informasi yang paling banyak digunakan oleh mahasiswa dalam mencari informasi tentang Program Studi adalah website Sekolah Pascasarjana IPB. Website ini dapat dimanfaatkan secara optimal oleh program pascasarjana dengan meningkatkan pengelolaan website Departemen ESL FEM IPB sebagai unit pengelola Program Studi di Departemen ESL. Website Departemen ESL telah tersambung langsung dengan website Sekolah Pascsarjana IPB. Namun, konten yang ada dalam website Departemen ESL perlu dilakukan updating mengenai informasi tentang program pascasarjana di Departemen ESL FEM IPB.

Sumber informasi kedua yang paling banyak digunakan oleh mahasiswa dalam mencari informasi tentang program pascasarjana di Departemen ESL adalah internet. Hal ini menjadi peluang besar yang dapat digunakan oleh program pascasarjana Departemen ESL FEM IPB untuk secara serius mengelola promosi dengan memanfaatkan media internet, terutama dengan membentuk tim khusus yang menangani promosi di Departemen ESL sebagai pengelola Program Studi. Karena selama ini belum ada bagian yang khusus dalam pengelolaan promosi melalui internet seperti memanfaatkan media sosial dan yang lainnya. Hal ini sesuai dengan penelitian yang dilakukan Renata dan Tobari (2017) bahwa salah satu promosi yang efektif dapat dilakukan melalui internet.

Program pascasarjana di Departemen ESL FEM IPB memiliki kompetensi yang spesifik, sehingga perlu juga dilakukan promosi secara spesifik. Hal ini sejalan dengan hasil penelitian yang menunjukkan bahwa sebagian besar mahasiswa yang memutuskan melanjutkan studi pada program pascasarjana di Departemen ESL FEM IPB adalah sudah memiliki pekerjaan yang tetap, 
baik sebagai peneliti, tenaga ahli, dosen, pegawai, karyawan, kepala bagian, baik di pemerintahan maupun di swasta. Beberapa responden yang memutuskan tidak melanjutkan studi adalah karena tidak turunnya ijin dari lembaga/instansi tempat mahasiswa bekerja dan tidak lolosnya beasiswa dari sponsor. Oleh karena itu, perlu dilakukan promosi secara langsung ke lembaga sponsor beasiswa dan juga ke instansi/lembaga tempat mahasiswa bekerja. Hasil wawancara langsung dengan aktor bahwa perlu adanya pembentukan tim khusus promosi di tingkat Sekolah Pascasarjana bekerja sama dengan Fakultas, Departemen dan Program Studi dalam rangka memberikan informasi tentang Program Studi dan program yang ditawarkannya.

Kemauan sendiri merupakan unsur faktor yang menjadi prioritas ketiga dengan nilai bobot $(0,232)$. Kemauan sendiri menjadi motivasi tersendiri yang timbul dalam diri mahasiswa yang memiliki pengaruh dalam memutuskan pilihan. Hasil penelitian menunjukkan bahwa kemauan sendiri menjadi faktor yang secara signifikan memengaruhi keputusan mahasiswa memilih program pascasarjana di Departemen ESL FEM IPB. Hal ini sejalan dengan hasil penelitian yang dilakukan oleh Artini et al. (2014) dengan menggunakan analisis faktor menemukan bahwa kemauan sendiri menjadi salah satu faktor yang signifikan memengaruhi keputusan mahasiswa memilih jurusan di Fakultas Ekonomi dan Bisnis UNDIKSHA.

Hasil wawancara langsung dengan responden menunjukkan bahwa kemauan sendiri mahasiswa memengaruhi cukup kuat terhadap Program Studi yang ditawarkan. Hal yang menarik dari hasil penelitian dapat dikemukakan bahwa mahasiswa yang memiliki kemauan sendiri yang kuat dalam memutuskan melanjutkan studi di program pascasarjana Departemen ESL FEM IPB demi memenuhi secara administrasi penerimaan mahasiswa baru, rela mengulang kembali melanjutkan studi Program Magister untuk selanjutnya dapat melanjutkan Program Doktor di program pascasarjana Departemen ESL FEM IPB. Wawancara lebih dalam dilakukan untuk mengetahui lebih lanjut alasan yang dikemukakan oleh mahasiswa terhadap kemauan sendiri tersebut menunjukkan bahwa program yang ditawarkan oleh program pascasarjana di Departemen ESL FEM IPB spesisfik, unik dan terbaik sesuai dengan kemauannya.

\section{Analisis Unsur Aktor terhadap Prioritas Alternatif Kebijakan untuk Meningkatkan Jumlah Mahasiswa}

Analisis aktor bertujuan mengetahui tingkat pengaruh suatu unsur aktor pada level kedua terhadap faktorfaktor yang terdapat pada level pertama. Unsur aktor meliputi Ketua Program Studi, Ketua Departemen ESL, mahasiswa, alumni, dosen, Dekan SPs IPB dan Dekan FEM. Berikut merupakan pembobotan unsur aktor untuk menyusun prioritas alternatif kebijakan untuk meningkatkan jumlah mahasiswa yang dapat dilihat pada Tabel 3 .

Tabel 3 menunjukkan bahwa bobot nilai tertinggi aktor yang memiliki peran paling berpengaruh adalah Ketua Program Studi $(0,242)$. Hal ini sesuai dengan peran penting Ketua Program Studi dalam hirarki struktural dalam pengelolaan operasional Program Studi. Sesuai struktur organisasi dan tupoksi, Ketua Program Studi merupakan pucuk pimpinan yang memegang komando utama dalam pengelolaan Program Studi. Namun, begitu dalam tugas dan tanggung jawab untuk penyelenggaraan Program Studi yang dipimpinnya, seperti dalam mengambil keputusan strategis perlu koordinasi dan pertimbangan Ketua Departemen. Ketua Program Studi juga berkoordinasi dengan Sekolah Pascasarjana IPB dan menjadi penghubung antara Departemen ESL FEM IPB dengan Sekolah Pascasarjana IPB.

Ketua Departemen ESL sebagai aktor yang memiliki pengaruh kedua dengan bobot nilai $(0,168)$ memiliki peran dalam pengantar perumusan alternatif kebijakan dalam peningkatan jumlah mahasiswa yang dilakukan oleh Ketua Program Studi secara struktural. Ketua Departemen ESL sebagai unit pengelola Program Studi bertanggung jawab terhadap keseluruhan pelaksanaan tata pamong Departemen ESL mulai dari perencanaan, pembiayaan, pelaksanaan, hingga evaluasi program kerja, baik internal maupun eksternal. Setiap kebijakan yang dirumuskan oleh Program Studi selalu dikoordinasikan kepada Departemen ESL FEM IPB, yang kemudian dihantarkan untuk disampaikan ke Sekolah Pascasarjana IPB dengan tetap mengacu kepada aturan yang telah ditetapkan oleh Rektor IPB.

Aktor selanjutnya yang memiliki pengaruh ketiga dengannilaibobot $(0,139)$ adalahmahasiswa.Mahasiswa merupakan input penting dalam penyelenggaraan pendidikan program pascasarjana di Departemen 
ESL FEM IPB. Sebagaimana yang dikemukakan pada Undang-Undang Pendidikan Tinggi Nomor 12 Tahun 2012 bahwa mahasiswa sebagai anggota sivitas akademika diposisikan sebagai insan dewasa yang memiliki kesadaran sendiri dalam mengembangkan potensi diri di Perguruan Tinggi untuk menjadi intelektual, ilmuwan, praktisi, dan/atau profesional. Hal ini menunjukkan bahwa mahasiswa selain sebagai insan yang dewasa, namun juga sebagai konsumen dalam pemasaran jasa yang memiliki peran sebagai penyampai informasi tentang Program Studi kepada masyarakat umum. Ketika dalam menjalani pendidikan di program pascasarjana di Departemen ESL mengalami kepuasan, maka informasi yang baik akan disampaikan kepada khalayak, termasuk memberikan rekomendasi kepada instansi/lembaga tempat mahasiswa bekerja. Hal ini perlu diperhatikan oleh program pascasarjana untuk memberikan pelayanan yang terbaik kepada mahasiswa, baik pelayanan akademik maupun non akademik, sehingga citra program pascasarjana yang baik tersebut melekat pada mahasiswa.

Alumni merupakan aktor yang memiliki pengaruh keempat dengan nilai bobot $(0,131)$. Alumni adalah mahasiswa yang telah lulus menempuh pendidikan Pascasarjana. Sebagaimana yang dinyatakan dalam Undang-Undang Pendidikan Tinggi bahwa lulusan program magister berhak menggunakan gelar magister dan lulusan program doktor berhak menggunakan gelar doktor. Sebagai intektual dewasa yang memiliki kompetensi dalam bidangnya, lulusan program pascsarjanajuga dapatmemberikan informasi yangnyata tentang pendidikan yang telah ditempuhnya. Termasuk pelayanan baik akademik maupun non akademik yang dapat disampaikan kembali kepada masyarakat dan juga di tempat kerjanya setelah para alumni tersebut kembali bekerja. Hal ini penting diperhatikan untuk program pascasarjana di Departemen ESL menjalin komunikasi yang baik dengan para alumni.

Aktor kelima yang tidak bisa dianggap sederhana dalam perannya adalah dosen dengan nilai bobot $(0,118)$. Jumlah minimal dan kualitas dosen juga menjadi syarat dalam pengelolaan suatu Program Studi. Dosen menurut Undang-Undang Perguruan Tinggi Nomor 12 Tahun 2012 merupakan anggota sivitas akademika memiliki tugas mentransformasikan ilmu pengetahuan dan/atau teknologi yang dikuasainya kepada mahasiswa dengan mewujudkan suasana belajardan pembelajaran sehingga mahasiswa aktif mengembangkan potensinya. Peran ini penting memberikan kesan yang baik bagi mahasiswa selama menempuh studi di Program Pascsarjana di Departemen ESL FEM. Di samping itu juga Dosen dapat membantu melakukan promosi Program Studi ke masyarakat dalam menjalankan tugas penelitian dan pengabdian kepada masyarakat.

Aktor yang memiliki pengaruh keenam selanjutnya adalah Dekan Sekolah Pascasarjana IPB (SPs IPB) dengan nilai bobot $(0,111)$. Peran penting Dekan Sekolah Pascasarjana (SPs) diantaranya adalah mengkoordinasikan pelaksanaaan pendidikan tingkat Pascasarjana untuk Program Studi monodisiplin serta dapat menyelenggarakan program tersebut yang bersifat interdisiplin atau multidisiplin di dalam IPB maupun dengan lembaga lain. Peran SPs IPB yang lainnya adalah penerimaan mahasiswa baru program pascasarjana terintegrasi pada kegiatan penerimaan mahasiswa baru multistrata dengan mengacu pada sistem yang berlaku di IPB, pelaksanaan koordinasi mata kuliah wajib Sekolah Pascasarjana, penjaminan mutu pendidikan tingkat Pascasarjana di lingkungan IPB dan melakukan promosi bersama.

Tabel 3 Bobot dan prioritas aktor terhadap alternatif kebijakan untuk meningkatkan jumlah mahasiswa

\begin{tabular}{lcc}
\hline Aktor & Bobot & Prioritas \\
\hline Ketua Program Studi & 0,242 & 1 \\
Ketua Departemen ESL & 0,168 & 2 \\
Mahasiswa & 0,139 & 3 \\
Alumni & 0,131 & 4 \\
Dosen & 0,118 & 5 \\
Dekan SPs IPB & 0,111 & 6 \\
Dekan FEM & 0,090 & 7 \\
\hline
\end{tabular}


Hasil wawancara langsung dengan pihak Dekan menyatakan akan dibentuk dewan, yaitu sekumpulan orang yang bertanggungjawab secara khusus untuk menangani promosi. Dewan ini beranggotakan dari Sekolah Pascasarjana IPB, Program Studi, Fakultas, dan Departemen untuk mendukung upaya meningkatkan jumlah mahasiswa. Hal ini perlu dilakukan, karena mahasiswa program pascasarjana memiliki karakteristik yang berbeda dengan Program Sarjana. Sekolah Pascasarjana IPB juga mendorong kerjasama dengan beberapa lembaga penelitian dengan program by riset untuk Program Magister dan Doktor. Sekolah Pascasarjana menawarkan program kepada lembaga-lembaga yang memiliki staf yang tidak bisa untuk menempuh kelas reguler akan difasilitasi dengan program by riset tersebut sehingga para staf masih bisa melanjutkan studi tanpa meninggalkan pekerjaannya, seperti LIPI.

Dekan Fakultas Ekonomi dan Manajemen (FEM) merupakan aktor yang memiliki peran ke tujuh dengan nilai bobot $(0,090)$. Fakultas dengan kewenangannya menyelenggarakan kegiatan dan penjaminan mutu akademik pada tingkat pendidikan sarjana, magister, dan doktor serta penelitian dan pengabdian pada masyarakat dalam satu atau seperangkat cabang ilmu pengetahuan. Dekan FEM juga memiliki peran mengkoordinir penyelenggaraan program akademik di FEM serta melaksanakan fungsi penjaminan mutu program pendidikan yang diampu oleh departemen di lingkungan FEM. Dengan perannya tersebut mutu program pascasarjana di Departemen ESL dapat terus dipertahankan dan menjadi informasi yang penting untuk masyarakat tentang Program Studi yang dapat dijadikan tempat untuk melanjutkan pendidikan.

\section{Analisis Unsur Alternatif Kebijakan terhadap Prioritas Kebijakan untuk Meningkatkan Jumlah Mahasiswa}

Analisis unsur alternatif kebijakan untuk mengetahui alternatif kebijakan yang menjadi prioritas untuk meningkatkan jumlah mahasiswa. Alternatif kebijakan yang dilakukan diurutkan berdasarkan bobot. Prioritas alternatif kebijakan berdasarkan bobot disajikan pada Tabel 4.

Tabel 4 menunjukkan lima alternatif kebijakan berdasarkan bobot nilai yang tertinggi. Pertama, menawarkan kerja sama ke beberapa lembaga baik di dalam negeri maupun di luar negeri $(0,347)$. Kedua, promosi langsung ke lembaga pemerintah dan swasta $(0,258)$. Ketiga, promosi dengan memanfaatkan media sosial yang ada $(0,243)$. Keempat, membuka program peminatan dan menawarkan program yang kompetitif $(0,152)$.

Menawarkan kerjasama ke beberapa lembaga baik di dalam negeri maupun di luar negeri merupakan alternatif kebijakan yang memiliki nilai bobot tertinggi $(0,347)$. Hal ini sesuai dengan hasil wawancara langsung dengan para aktor yang sebagian besar menyatakan bahwa dengan spesifiknya Program Studi yang ditawarkan oleh program pascasarjana di Departemen ESL FEM IPB, maka menawarkan kerjasama ke beberapa lembaga baik di dalam negeri maupun luar negeri penting untuk dilakukan. Hal ini untuk lebih memantapkan lembaga yang bersangkutan semakin jelas mengetahui dan mendapatkan informasi program yang ditawarkan sesuai dengan kompetensi yang dibutuhkan oleh lembaga yang bersangkutan. Sejalan dengan hasil penelitian menunjukkan bahwa sebagian besar mahasiswa yang tidak jadi memutuskan melanjutkan pendidikan karena ijin tidak turun dari pimpinan lembaga tempat mahasiswa bekerja.

Tabel 4. Bobot dan prioritas alternatif kebijakan terhadap prioritas kebijakan untuk meningkatkan jumlah mahasiswa

\begin{tabular}{lcc}
\hline Alternatif & Bobot & Prioritas \\
\hline Menawarkan kerja sama ke beberapa lembaga baik di dalam negeri maupun di luar negeri & 0,347 & 1 \\
Promosi langsung ke lembaga pemerintah dan swasta & 0,258 & 2 \\
Promosi dengan memanfaatkan media sosial yang ada & 0,243 & 3 \\
Membuka program peminatan dan menawarkan program yang kompetitif & 0,152 & 4 \\
\hline
\end{tabular}


Alternatif kebijakan dengan urutan prioritas kedua adalah promosi langsung ke lembaga pemerintah dan swasta $(0,258)$. Hasil wawancara dengan para aktor menunjukkan bahwa sebagian besar menyatakan bahwa promosi langsung ke lembaga pemerintah dan swasta penting dilakukan untuk memberikan informasi tentang Program yang ditawarkan. Beberapa aktor menyatakan bahwa informasi mengenai Program Studi yang ditawarkan oleh program pascasarjana di Departemen ESL dengan adanya persaingan yang kompetitif dari beberapa Program Studi yang serumpun tidak banyak didapatkan oleh lembaga baik swasta maupun pemerintahan. Dinyatakan juga dari beberapa aktor bahwa Program Studi yang lain telah melakukan promosi secara masif ke beberapa lembaga pemerintah dan swasta dalam upaya meningkatkan jumlah mahasiswa. Sejalan dengan penelitian Asmiati et al. (2014) bahwa strategi promosi langsung dapat dilakukan secara efektif ke daerah-daerah dalam memperkenalkan program studi termasuk dengan menawarkan beasiswa.

Promosi dengan memanfaatkan media sosial yang ada merupakan alternatif kebijakan yang ketiga dengan bobot nilai $(0,243)$. Sejalan dengan hasil penelitian yang menunjukkan bahwa sumber informasi yang paling banyak digunakan oleh mahasiswa adalah website Sekolah Pascasarjana IPB dan internet. Kebijakan ini penting dilakukan untuk menjawab perkembangan teknologi terutama di era millennial sekarang. Perkembangan teknologi yang cukup signifikan terlihat mayoritas konsumen pasar Perguruan Tinggi menggunakan teknologi internet dalam rangka mencari informasi tentang apapun, termasuk informasi tentang Program Studi yang akan dimasukinya.

Alternatif kebijakan keempat dengan nilai bobot $(0,152)$ adalah membuka program peminatan dan menawarkan program yang kompetitif. Kebijakan ini penting dilakukan dengan semakin banyaknya program serumpun yang bermunculan dan spesifik yang mengikutikebutuhan pasarduniakerja. Hasil wawancara langsung sebagian besar para aktor menyatakan bahwa program yang kompetitif semakin banyak ditawarkan oleh Program Studi yang lain. Begitu juga dengan program peminatan telah dilakukan oleh beberapa program pascasarjana yang lain. Hal ini sejalan dengan hasil penelitian yang menunjukkan bahwa faktor yang signifikan mempengaruhi keputusan mahasiswa memilih program pascasarjana di Departemen ESL FEM IPB adalah produk (Program Studi).
Pengolahan Horizontal

Menurut Marimin dan Maghfiroh (2010) pengolahan horizontal dimaksudkan untuk menyusun prioritas elemen keputusan setiap tingkat hirarki keputusan. Pengolahan horisontal ini menganalisis unsur aktor pada level kedua dan unsur alternatif pada level kedua. Unsur aktor dan unsur alternatif yang digunakan berdasarkan hierarki yang dibangun.

\section{Unsur Aktor terhadap Faktor yang Memengaruhi Keputusan Mahasiswa Memilih Program Pascasarjana di Departemen ESL}

Analisis aktor bertujuan melihat tingkat pengaruh suatu unsur aktor pada level kedua terhadap faktorfaktor yang terdapat pada level pertama. Unsur aktor yang digunakan berjumlah lima dan unsur faktor yang digunakan adalah tiga. Pembobotan unsur aktor penyusun alternatif kebijakan untuk meningkatkan jumlah mahasiswa tersaji pada Tabel 5 .

Tabel 5 menunjukkan bahwa bahwa Ketua Program Studi menjadi aktor penting dalam upaya meningkatkan jumlah mahasiswa, terutama pada faktor produk dengan nilai bobot $(0,293)$ dan faktor promosi dengan nilai bobot $(0,267)$. Sedangkan aktor penting yang berperan dalam faktor kemauan sendiri adalah mahasiswa dengan nilai bobot $(0,359)$. Pentingnya peran Ketua Program Studi bagi upaya peningkatan jumlah mahasiswa perlu diperhatikan dengan peningkatan pengelolaan Program Studi yang lebih serius dan melakukan promosi secara rutin. Selain itu, peran mahasiswa penting dalam meningkatkan jumlah mahasiswa berkaitan dengan kepuasan mahasiswa selama menjalani pendidikan pada program pascasarjana di Departemen ESL FEM IPB. Sehubungan dengan hal tersebut, untuk lebih meningkatkan kemauan sendiri mahasiswa, maka program pascasarjana di Departemen ESL FEM IPB perlu meningkatkan pelayanan baik akademik maupun non akademik dan melakukan evaluasi pelayanan yang dilakukan secara rutin. Hal ini berbanding lurus dengan hasil wawancara mendalam bahwa sebagian aktor menyatakan bahwa ada kesan yang terbangun pada program pascasarjana di Depertemen ESL FEM IPB dalam proses penyelesaian tugas akhir yang cukup lama sehingga dapat menyebabkan keraguan calon mahasiswa. 


\section{Unsur Alternatif Kebijakan terhadap Aktor}

Analisis alternatif kebijakan bertujuan untuk melihat pengaruh suatu unsur alternatif kebijakan terhadap aktor-aktor yang berada pada level kedua. Unsur aktor pada level kedua yang digunakan adalah berjumlah tujuh. Pembobotan unsur alternatif kebijakan untuk meningkatkan jumlah mahasiswa disajikan pada Tabel 6. Tingkat kepentingan aktor terhadap alternatif kebijakan untuk meningkatkan jumlah mahasiswa. Berdasarkan tabel tersebut diketahui bahwa aktor Dekan SPs IPB, Dekan FEM IPB, Ketua Dept.ESL, dan Ketua Program Studi lebih memprioritaskan kebijakan menawarkan kerjasama ke beberapa lembaga baik di dalam negeri maupun di luar negeri dengan nilai bobot masing-masing sebesar $(0,465),(0,490),(0,432)$, dan $(0,434)$. Sedangkan Dosen lebih memprioritaskan strategi promosi langsung ke lembaga pemerintah dan swasta dengan nilai bobot sebesar 0,306. Selain itu, mahasiswa dan alumni lebih memprioritaskan strategi promosi dengan memanfaatkan media sosial yang ada dengan bobot sebesar $(0,400)$ dan $(0,384)$. Sehubungan dengan hal tersebut penting melakukan promosi secara bersama yang dilakukan oleh Dekan SPs IPB, Dekan FEM, Ketua Departemen ESL dan Ketua Program Studi termasuk melibatkan dosen dalam upaya meningkatkan jumlah mahasiswa supaya lebih terintegrasi. Promosi melalui media sosial perlu juga diperhatikan dengan serius pengelolaannya karena menjadi salah satu sumber informasi yang banyak digunakan oleh mahasiswa. Hasil wawancara mendalam dengan para aktor sebagain besar menyatakan bahwa promosi belum dilakukan dengan baik dan optimal oleh program pascasarjana di Departemen ESL FEM IPB. Sehingga belum banyak menarik mahasiswa meskipun spesialisasi keilmuan mencakup lingkungan merupakan isu global dan juga aspek-aspek ekonomi pertanian.

Tabel 5. Bobot pengolahan horisontal unsur aktor terhadap unsur faktor

\begin{tabular}{lccc}
\hline \multirow{2}{*}{ Aktor } & \multicolumn{2}{c}{ Faktor } \\
\cline { 2 - 4 } & Produk & Promosi & Kemauan Sendiri \\
\hline Dekan SPs IPB & 0,132 & 0,111 & 0,066 \\
Dekan FEM IPB & 0,095 & 0,111 & 0,055 \\
Ketua Dept.ESL & 0,200 & 0,190 & 0,073 \\
Ketua Program Studi & 0,293 & 0,267 & 0,104 \\
Dosen & 0,137 & 0,097 & 0,100 \\
Mahasiswa & 0,063 & 0,093 & 0,359 \\
Alumni & 0,080 & 0,132 & 0,243 \\
Inconsistency ratio & 0,010 & 0,010 & 0,010 \\
\hline
\end{tabular}

Tabel 6. Bobot pengolahan horisontal unsur alternatif kebijakan terhadap unsur aktor

\begin{tabular}{|c|c|c|c|c|c|c|c|}
\hline \multirow[b]{2}{*}{ Alternatif Kebijakan } & \multicolumn{7}{|c|}{ Aktor } \\
\hline & $\begin{array}{l}\text { Dekan SPs } \\
\text { IPB }\end{array}$ & $\begin{array}{l}\text { Dekan } \\
\text { FEM IPB }\end{array}$ & $\begin{array}{c}\text { Ketua } \\
\text { Dept. ESL }\end{array}$ & $\begin{array}{l}\text { Ketua } \\
\text { Program } \\
\text { Studi }\end{array}$ & Dosen & Mahasiswa & Alumni \\
\hline $\begin{array}{l}\text { Membuka program peminatan } \\
\text { dan menawarkan program yang } \\
\text { kompetitif }\end{array}$ & 0,135 & 0,118 & 0,133 & 0,207 & 0,162 & 0,145 & 0,109 \\
\hline $\begin{array}{l}\text { Promosi langsung ke lembaga } \\
\text { pemerintah dan swasta }\end{array}$ & 0,273 & 0,255 & 0,282 & 0,189 & 0,306 & 0,254 & 0,285 \\
\hline $\begin{array}{l}\text { Promosi dengan memanfaatkan } \\
\text { media sosial yang ada }\end{array}$ & 0,127 & 0,137 & 0,154 & 0,17 & 0,292 & 0,400 & 0,384 \\
\hline $\begin{array}{l}\text { Menawarkan kerjasama ke } \\
\text { beberapa lembaga baik di dalam } \\
\text { negeri maupun di luar negeri }\end{array}$ & 0,465 & 0,490 & 0,432 & 0,434 & 0,239 & 0,201 & 0,221 \\
\hline Inconsistency ratio & 0,01 & 0,01 & 0,00 & 0,01 & 0,02 & 0,00 & 0,00 \\
\hline
\end{tabular}




\section{Implikasi Manajerial}

Perlu adanya peningkatan perhatian pengelolaan dan pengembangan program oleh Ketua Program Studi dan Ketua Departemen ESL secara serius dan berkomitmen tinggi. Penawaran kerjasama ke beberapa lembaga baik di dalam negeri maupun di luar negeri perlu dipersiapkan dengan matang dan dilakukan secara terencana dan rutin. Di samping itu, Program Studi juga perlu melakukan promosi langsung ke lembaga pemerintah dan swasta secara rutin dan dikelola dengan serius. Ketua Program Pacasarjana di Departemen ESL FEM IPB berkoordinasi dengan Ketua Departemen ESL untuk melakukan peningkatan pengelolaan website Departemen ESL FEM IPB. Hal ini dilakukan untuk sarana promosi yang telah disambungkan dengan website Sekolah Pascasarjana IPB. Website SPs IPB sebagai sumber informasi yang mendominasi dimanfaatkan oleh mahasiswa dalam mencari informasi tentang Program Studi. Hal ini dapat dilakukan dengan membentuk tim khusus promosi di Departemen ESL FEM IPB untuk melakukan promosi dan peningkatan pengelolaan yang serius website program pascasarjana di Departemen ESL FEM. Karena selama ini pengelolaan website tersebut belum menjadi perhatian serius oleh program pascasarjana di Departemen ESL dan Departemen ESL sebagai homebase. Program pascasarjana di Departemen ESL FEM IPB perlu meningkatkan promosi dengan membangun komunikasi dan kerjasama yang baik dengan instansi/lembaga tempat bekerja mahasiswa dan alumni.

\section{KESIMPULAN DAN SARAN}

\section{Kesimpulan}

Faktor yang menjadi prioritas secara keseluruhan adalah produk (Program Studi). Aktor yang menjadi prioritas secara keseluruhan, yaitu Ketua Program Studi. Strategi yang menjadi prioritas secara keseluruhan dalam upaya meningkatkan jumlah mahasiswa adalah menawarkan kerjasama ke beberapa lembaga baik di dalam maupun di luar negeri.

\section{Saran}

Peningkatan peran semua aktor penting dalam kebijakan meningkatkan jumlah mahasiswa perlu dilakukan. Hal ini dilakukan supaya dapat mengoptimalkan peningkatan jumlah mahasiswa program pascasarjana di Departemen ESL FEM IPB. Penelitian selanjutnya perlu memperluas ruang lingkup penelitian dan melibatkan aktor stakeholder, sehingga lebih banyak lagi informasi yang dapat diperoleh.

\section{DAFTAR PUSTAKA}

Artini IDAJ, Kirya IK, Suwendra IW. 2014. Faktorfaktor yang mempengaruhi keputusan mahasiswa dalam memilih jurusan di Fakultas Ekonomi dan Bisnis (FEB) Universitas Pendidikan Ganesha (Undiksha) sebagai tempat kuliah. E-Journal Bisma Universitas Pendidikan Ganesha Jurusan Manajemen 2(2): 1-8.

Asmiati, Akbar M, Sultan I. 2014. Strategi promosi Universitas Islam Negeri Alauddin Makassar dalam meningkatkan jumlah calon mahasiswa pasca peralihan dari Institut menjadi Universitas. Jurnal Komunikasi KAREBA 3(1): 8-14.

Dharmawansyah S, Cangar H, Sultan MI. 2014. Strategi promosi dalam meningkatkan jumlah mahasiswa pada Politeknik Negeri Media Kreatif Makassar. Jurnal Komunikasi KAREBA 3(4): 8-14.

Erdawati. 2014. Pengaruh motivasi, persepsi dan promosi terhadap keputusan mahasiswa memilih STIE Pasaman Simpang Empat. E-Jurnal Apresiasi Ekonomi 2(3): 153-159.

Fakhri M, Gilang A, Ratnayu N. 2017. Analisis faktor pembentuk keputusan pemilihan perguruan tinggi swasta Universitas Telkom. Jurnal Ekonomi, Bisnis \& Entrepreneurship 11(1): 1-12.

Harwani Y, Suharjo B, Nurmalina R, Suprayitno G. 2018. Brand name and customers' intention. European Research Studies Journal 21 (3): 299 315. https://doi.org/10.35808/ersj/1062.

Ichwani TH, Arief D, Anas MF. 2019. Strategi peningkatan keberlanjutan daya saing teh organik. Jurnal Aplikasi Manajemen dan Bisnis 5(1): 109-120. https://doi.org/10.17358/ jabm.5.1.109.

[IPB] Institut Pertanian Bogor. 2018. Borang Akreditasi Program Pascasarjana Departemen ESL FEM IPB. Bogor: IPB

Jayawinangun R, Syamsun M, Sarma M. 2014. Efektivitas promosi kunjungan sekolah pada mahasiswa baru program strata S1 Institut Pertanian Bogor [tesis]. Bogor: Institut Pertanian Bogor.

Kurniawati D. 2013. Pengaruh strategi bauran 
pemasaran terhadap keputusan mahasiswa memilih Universitas Katolik Widya Mandala Madiun. Widya Warta 2(1): 65-80.

Mahmudah, Baga LM, Amanah S. 2019. Analisis faktor-faktor yang memengaruhi keputusan mahasiswa memilih program pascasarjana. Jurnal Tadbir Muwahhid 3(2): 97-117. https:// doi.org/10.30997/jtm.v3i2.1868.

Marimin, Maghfiroh N. 2010. Aplikasi Teknik Pengambilan Keputusan dalam Manajemen Rantai Pasok. Bogor: IPB Press.

Mulyatini S, Suharyati, Handayani T. 2014. Faktorfaktor yang berpengaruh terhadap keputusan memilih Program Studi. Fakultas Ekonomi UPN Veteran Jakarta. JPU 2(2): 1-15.

Renata, Tobari. 2017. Strategi promosi dalam meningkatkan jumlah mahasiswa pada Perguruan Tinggi. JMKSP 2(1): 23-32.

Saaty T. 1993. Pengambilan Keputusan. Jakarta: Pustaka Binaman Pressindo.

[Sekneg] Sekretariat Negara. 2005. Peraturan Pemerintah Nomor 19 Tahun 2005 tentang standar nasional pendidikan. Jakarta: Sekretariat Negara.

[Sekneg] Sekretariat Negara. 2012. Undang-Undang Republik Indonesia Nomor 12 Tahun 2012. Jakarta: Sekretariat Negara.

Setyowati ES, Aesthetika NM. 2017. Pengaruh bauran promosi terhadap pengambilan keputusan memilih Universitas Muhammadiyah Sidoarjo (UMSIDA). Jurnal Ilmu Komunikasi KANAL 5(2): 131-140. https://doi.org/10.21070/kanal. v5i2.1481.

Siregar S, Panjaitan N. 2018. Promosi dan pemetaan mahasiswa baru Program Studi (S1) Teknik Sipil
Jurusan Pendidikan Teknik Bangunan Fakultas Teknik Unimed. Jurnal Education Building 4(1): 33-39. https://doi.org/10.24114/eb.v4i1.10042.

Sugiyono. 2007. Statistika untuk Penelitian. Revisi terbaru cetakan ke-12. Bandung: CV Alfabeta.

Suhud, Dwiyatno S. 2014. Analisis pendukung keputusan penentuan media promosi penerimaan mahasiswa baru Universitas Serang Raya menggunakan metode AHP. Jurnal PROSISKO 1(1): 30-35.

Sumarwan U, Fachrozi A, Nursal A, Nugroho A, Nurzal ER, Setiadi IA, Suharyono, Alamsyah Z. 2013. Pemasaran Strategik: Perspektif Value-Based dan Pengukuran Kinerja. Cetakan ke-3. Bogor: IPB Press.

Topan T. 2018. Penawaran perkuliahan online juga telah dilakukan oleh beberapa perguruan tinggi terbaik di Indonesia. https://www.idntimes. com/life/education/rosma-stifani/6-universitasterbaik-di-indonesia-ini-tawarkan-programkuliah-online-lho-c1c2/full. [2018 Des 12].

Triyonggo Y. 2016. Rancang bangun model pengembangan kompetensi profesi manajemen sumberdaya manusia di Indonesia [disertasi]. Bogor: Institut Pertanian Bogor.

Wiliana E. 2018. Analisis Faktor-faktor yang mempengaruhi keputusan mahasiswa dalam memilih programstudidiFakultas IlmuKesehatan Universitas Muhammadiyah Tangerang. Jurnal JKFT 1(1): 71-78.

Wulandini P, Saputra R. 2017. Pengambilan keputusan mahasiswa dalam memilih perguruan tinggi swasta di Pekanbaru. Jurnal Sains Sosial dan Humaniora 1(2): 93-102. 